\title{
IMMIGRANTS’ USE OF LANGUAGE FOR PROFESSIONAL PURPOSES IN A HOST COUNTRY: IMPLICATIONS FOR ADULT EDUCATION
}

\author{
Andreas Ahrens \\ Hochschule Wismar, Germany \\ Jeḷena Zaščerinska \\ Centre for Education and Innovation Research, Latvia
}

\begin{abstract}
By 2050 the flow of climate immigrants is repeatedly predicted to be about 200 million. Immigrants' employment in a host country has become a hot issue. To empower immigrants' employability, structural features, e.g. adult education, can assist with providing a proper training to immigrants. The aim of the present paper is to carry out an empirical study on immigrants' use of language for professional purposes in a host country underpinning elaboration of implications for adult education. The empirical study was carried out at Klaipeda University, Klaipeda, Lithuania, on the $24^{\text {th }}$ October 2019. Focus interview served as the basis for data collection. Theoretical analysis results in the establishment of interconnections between immigrants' use of mother tongue, foreign language as well as host country's language at work in a host country. The conclusion is drawn that the majority of immigrants uses their mother tongues at work in a host country. The empirical study reveals that local companies employ immigrants for establishing business connections between the immigrants' host country as well as immigrants' origin country. The paper's novel contribution is the newly formulated implications on immigrants' use of language for professional purposes for adult education. Directions of future work are proposed.
\end{abstract}

Keywords: foreign language, host country's language, immigrants, language for professional purposes, mother tongue, professional language, use of language.

\section{Introduction}

From outside Europe, high numbers of people arrive in the European Union (EU) searching for asylum or better life conditions (Eurostat, 2019). In the near future, human migration will be only increasing due to the impact of climate change (Pinto-Dobernig, 2008, p.9). Millions of people will be displaced by shoreline erosion, coastal flooding and agricultural disruption (Pinto-Dobernig, 2008, p.9). Since then various analysts have tried to put numbers on future flows of climate migrants (sometimes called "climate refugees") - the most widely repeated prediction being 200 million by 2050 (Pinto-Dobernig, 2008, p.9). 
Since arriving in a host country, immigrants often face such a challenge as finding a job or, in other words, unemployment. The evidence shows that the employment rate of immigrants is typically lower than that of natives and that their job opportunities mainly consist of low-skilled (and often precarious) work (Adser`a \& Pytlikov'a, 2016). Occupational, or in other words, professional activity as a purpose of language teaching pinpointed the principal sectors facing problems with recruitment which mainly attract foreign employees; they are the cleaning, catering and building sectors (Extramiana, 2012). Clearly, what are known as "unskilled jobs" primarily concern economic sectors recruiting foreign labour (Extramiana, 2012).Traditionally considered that fluency in the language of the destination, or in other words, host country can facilitate the transfer of migrants' skills to the new labour market, thus contributing to the global interchange of skills and stimulating economic growth (Pieroni, d'Agostino, \& Lanari, 2019). A study reveals that migrants with a low proficiency in the language of the destination country had particularly reduced opportunities in the labour market and documented that they were significantly affected by decreasing employment and increasing workplace discrimination (Pieroni, d'Agostino, \& Lanari, 2019). Immigrants with linguistic problems in the language of the destination country reduced their employment rate by about $30 \%$ and their expected wages relative to immigrants with good linguistic proficiency in the language of the destination country, suggesting that the tightening of the linguistic abilities of immigrants in host countries may significantly constraint the adverse impact on the individuals that were affected (Pieroni, d'Agostino, \& Lanari, 2019). Host country's language problems explained more than half of the wage inequalities between natives and immigrants, particularly for men (Pieroni, d'Agostino, \& Lanari, 2019). A wage gap of about $20 \%$ between immigrants with proficiency in the language of the destination country and those without proficiency in the language of the destination country is discovered, a magnitude that increases to 25\% for male immigrants (Pieroni, d'Agostino, \& Lanari, 2019). An important implication of the analysis for immigration policy is that immigrants proficient in the language of the destination country improve the opportunities in the economic, social and civic life of their new country (Pieroni, d'Agostino, \& Lanari, 2019).

In general, proficiency in foreign language or in other words, host country's language is named as a major factor presupposing economic, political and social well-being as shown in Figure 1 (Zaščerinska \& Melnikova, 2014). 


\section{Quality of life and well-being}

Host country's language proficiency

Figure 1 The relationship between well-being and host country's language proficiency (source: adapted from Zaščerinska \&Melnikova, 2014)

Structural features, such as education in general and adult education in particular, may help to deal with critical life phases successfully (Zaščerinska \& Melnikova, 2014). Consequently, language proficiency is a key focus in adult education. Effective design of a language course in adult education that operates within the learner-centred approach is based on needs analysis that clarifies reasons (study in a foreign country, working in a foreign company, etc) for which adult learners (including immigrants) learn (Zaščerinska \& Melnikova, 2014). Against this background, the hitherto research was mostly focused on issues and educational approaches to learning the language of the host country for professional purposes (Extramiana, 2012), the linguistic integration of adult migrants (Council of Europe Symposium, 2016), and the effects of language skills on immigrant employment and wages in Italy (Pieroni, d'Agostino, \& Lanari, 2019). The paper's aim is to carry out an empirical study on immigrants' use of language for professional purposes in a host country underpinning elaboration of implications for adult education. The methodological background of the presented research is based on System-Constructivist Theory, as opposed to behaviourism. System-Constructivist Theory emphasizes that reality is socially constructed, and constructing is the creative process based on knowledge variety (Zaščerinska, Ahrens, \& Andreeva, 2013). Constructive process is always situation-related (Ose, Surikova, Fernāte, Daniela, Kalnina, \& Maslo, 2008). The novel contribution of the paper is the newly formulated implications on immigrants' use of language for professional purposes for adult education.

\section{Conceptual Framework}

This part of the paper describes the main concepts underlying this research. The present research is built on three concepts as illustrated in Figure 2.

One of the concepts of the present work is multilingualism. The conceptual framework of the present research is based on such the approach to multilingualism as the coexistence of several languages within a given social group (Saulescu, Saulescu, \& Capatan, 2009) as depicted in Figure 3. 
Ahrens \& Zaščerinska, 2020. Immigrants' Use of Language for Professional Purposes in a Host Country: Implications for Adult Education

Multilingualism

\section{ConceptualFramework}

Languages for

professional purposes
Unity of all

language

Figure 2 Conceptual framework of the present research (source: authors)

Mother tongue

Professional language

\section{Multilingualism}

Host

country's

language
Foreign

language

Figure 3 Languages of multilingualism (source: authors)

By professional language, native language for specific purposes is meant (Zaščerinska, 2010). Figure 4 reveals the differentiation of host country's language (Extramiana, 2012).

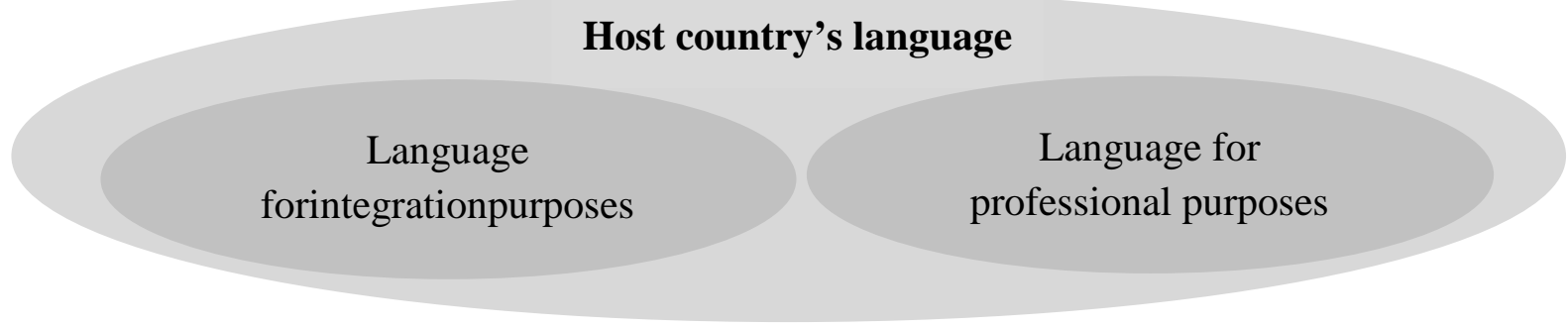

Figure 4 Elements of host country's language (source: authors)

It should be noted that if language competences are a component of integration, they cannot be a precondition for integration, since acquiring a language is potentially a lifelong process (Council of Europe Symposium, 2016). Another concept in the present research is language as the unity of all language (Robbins, 2007). This concept implies an individual who demonstrates a proficiency in mother tongue, foreign language, professional language and second language or, in other words, host country's language. These individual's languages are linked, united in various ways, forming a whole (Robbins, 2007, p. 51). The concept of languages for professional purposes means a work-related language (Extramiana, 2012). It should be pointed that languages for professional 
purposes are utilised within the implementation of a variety of professional activities in a working environment as shown in Figure 5.

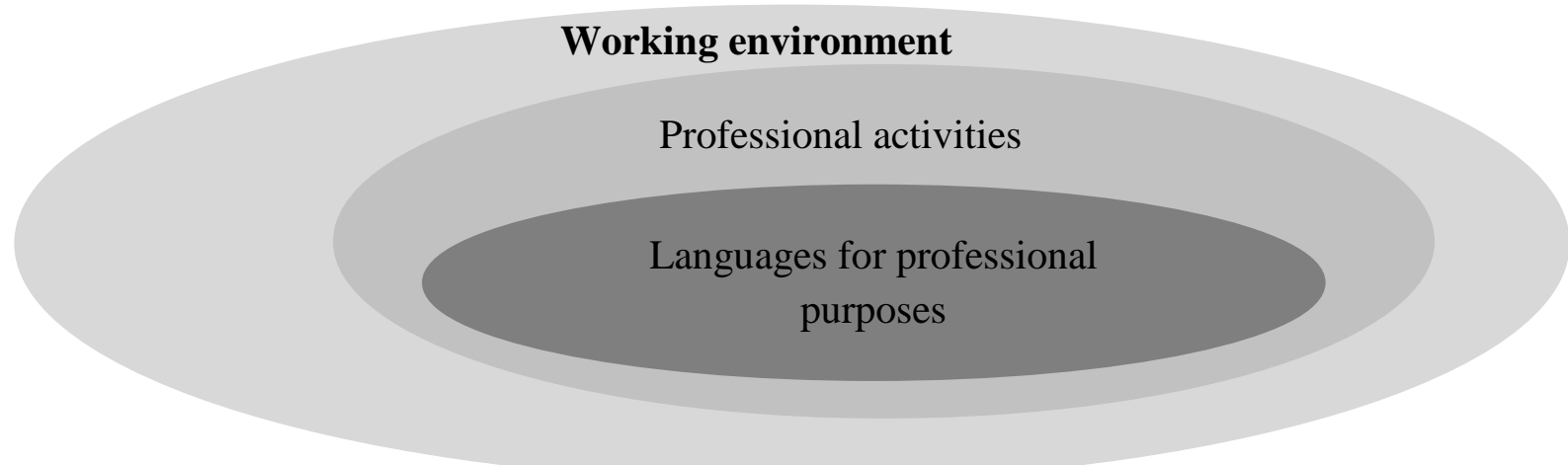

Figure 5 The inter-relations between working environment, professional activities as well as languages for professional purposes (source: authors)

Three particular professional purposes such as the logical organisation and presentation of ideas; business documents' detailed proof-reading; and the conventions of various writing genres, such as business emails and proposals are outlined.Immigrant's use of languages for professional purposes depends on a reason of immigration (Extramiana, 2012): labour immigration and family immigration. Labour immigration is characterized by obtaining employment (Extramiana, 2012). In order to pinpoint the needs in terms of language skills required for a given occupation, at least one important factor has to be taken into account, namely time: at what point in time in their integration procedure do speakers of other languages accede to the labour market? What language competences do they have when they enter employment? (Extramiana, 2012). Persons who have migrated for the purposes of family reunification will at some stage have to consider the question of their occupational integration, which in turn raises the issue of the requisite language competences (this does not usually apply to migrants over 65 years of age) (Extramiana, 2012). Or again, such persons may already be working in a sector that requires few language competences and may wish to further their career, in which case they will have to develop language skills (Extramiana, 2012). The link between the theoretical part of the study and the empirical data of the study is indicated: As mother tongue and professional language or, in other words, native language for specific purposes (Zaščerinska, 2010) mean individual's first language, for the empirical study only mother tongue, foreign language and/or host country's language are considered. The empirical study has to identify immigrants' use of languages (mother tongue, foreign language and/or host country's language) for the implementation of their professional activities in a host country in order to design an efficient language course for immigrants who take part in adult education. 
Ahrens \& Zaščerinska, 2020. Immigrants' Use of Language for Professional Purposes in a Host Country: Implications for Adult Education

\section{Methodology}

The present part of the paper demonstrates the design of the empirical study. It comprises the question and purpose, sample and methodology of the empirical study. The guiding question of the empirical study was as follows: Which languages (mother tongue, foreign language and/or host country's language) immigrants use for the implementation of their professional activities in their host country)? The purpose of the empirical study was to analyse immigrants' use of languages for professional purposes (mother tongue, foreign language and/or host country's language) in a host country. The empirical study was carried out during an international training event for adult educators at Klaipeda University, Klaipeda, Lithuania, on the $24^{\text {th }}$ October 2019. The present empirical study involved six respondents who were invited by Klaipeda University within the presentation of the research "Challenges of migrants' effective integration in to the international labour market" at the international training event, devoted to the development of immigrants' and asylum seekers' digital entrepreneurship, for adult educators. All the six respondents are immigrants arrived from different countries in Klaipeda, Lithuania. The sample of six respondents consisted of one female and five males. The age of the respondents differentiated from 23 to 50. Working experience of the respondents was different, too. The sample is multicultural as the respondents with different cultural backgrounds and diverse educational approaches from different countries, namely, Germany, Italy, Ukraine, Canada, Columbia and Uzbekistan, were chosen. The respondents' multicultural background emphasizes the significance of the study of the use of language for professional purposes of each respondent. Hence, the group's sociocultural context (age, field of study and work, language level, mother tongue, etc) is heterogeneous. In order to save the information of the present research confidential, the respondents' names and surnames are coded:R1 means a respondent from Germany, R2 - from Italy, R3 - from Ukraine, R4 - from Canada, R5 - from Columbia, R6 - from Uzbekistan.

As the topic of immigrants' use of languages for professional purposes in a host study is not studied in detail, an exploratory study was employed within the present work. The uncertainty in this particular research field does not allow following a formal structure of the study. The researcher is flexible to shape the methodology of the exploratory study. The present exploratory study aims at identifying the use of immigrants' languages for professional purposes (mother tongue, foreign language and/or host country's language) in a host country. The exploratory methodology of the empirical study proceeds from explorationin Phase 1 through analysis in Phase 2 to hypothesis/research question development in Phase 3 (Ahrens, Bassus, \& Zaščerinska, 2013, p. 104). 
The interpretive paradigm was used in the empirical study. The interpretive paradigm aims to understand other cultures, from the inside through the use of ethnographic methods such as informal interviewing and participant observation, etc (Taylor \& Medina, 2013). The interpretative research paradigm corresponds to the nature of humanistic (person-centred) pedagogy (Lūka, 2008). The interpretative paradigm creates an environment for the development of any individual and helps them to develop their potential (Lūka, 2008). The core of this paradigm is human experience, people's mutual everyday interaction that tends to understand the subjectivity of human experience (Lūka, 2007). The paradigm is aimed at understanding people's activity, how a certain activity is exposed in a certain environment, time, conditions, i.e., how it is exposed in a certain sociocultural context (Lūka, 2007). Interpretative paradigm is characterized by the researcher's practical interest in the research question (Cohen, Manion, \& Morrison, 2003). The researcher is the interpreter (Ahrens, Purvinis, Zaščerinska, Micevičienè, \&Tautkus, 2018).

Data collected from the sample of the present empirical study is relevant to adult education as the data clarifies the reasons of immigrants use of languages (mother tongue, foreign language and/or host country's language) for the implementation of their professional activities in their host country. The identified reasons will help in designing an efficient language course in adult education as well as determining implications for adult education.

Data were collected via a structured interview as structured interview allows more consistency across responses to be obtained (Richards, 2001, p. 61). Structured interview is based on theoretical analysis (Kroplijs \& Raščevska, 2004, p. 99). Structured interview usually includes a set of series of questions (Richards, 2001, p. 61). Structured interview allows more consistency across responses to be obtained (Richards, 2001, p. 61). The structured interview of the present empirical study was based on such questions: Do you work in your host country? What kind of job do you do? What are your job responsibilities? Which language(s) (mother tongue, foreign language and/or host country's language) do you use at work? Which languages do you use for the implementation of your professional tasks at work? Which languages do you use with your clients? Which languages do you use with your colleagues? What are other languages you use for professional purposes?

Data were analysed via content analysis. Content analysis was done via summarizing content analysis. Summarizing content analysis seeks to reduce the material in such a way that the essential contents are preserved, but a manageable short text is produced (Mayring, 2004, p. 269). 
Ahrens \& Zaščerinska, 2020. Immigrants’ Use of Language for Professional Purposes in a Host Country: Implications for Adult Education

\section{Research Results}

The present part of the paper reveals the results of the interview and findings of the present study.

Respondent 1 (R1) arrived in Klaipeda, Lithuania, from Germany. He is about 50 years old. In Klaipeda, he works part-time in a Lithuanian company. His work responsibilities focus on communication with German partners of the host country's company. He does his job in his mother tongue, namely German.

Respondent 2 (R2) comes from Italy. He is about 45 years old. He works in a private company of the host country. The private company is family based. His responsibilities are to communicate with Italian partners on behalf of the company. His work communication is based on his mother tongue, namely Italian.

Respondent 3 (R3) is from Ukraine. She is about 40 years old. She works at a state school in Klaipeda, Lithuania. She teaches Russian language to Lithuanian schoolchildren. Her work duties are based on the use of her mother tongue, namely Russian.

Respondent 4 (R4) came to Klaipeda, Lithuania, from Canada. He is about 30 years old. He teaches English in a private language school in Klaipeda. He does his job in his mother tongue, namely English.

Respondent 5 (R5) was born in Columbia in about 50 years ago. He has some Lithuanian roots. That is why he came to Klaipeda, Lithuania, for living. However, he learned Lithuanian language, this is not his mother tongue. Consequently, he uses Lithuanian as a host country's language.

Respondent 6 (R6) came to Klaipeda, Lithuania, from Uzbekistan for studying medicine. He is about 25 years old. His university studies are in English. Considering studies as part of professional life and purposes, he uses a foreign language in the host country.

The structured interview resulted in the respondents' statements that four of them use mother tongue while doing a job. One respondent utilizes host country's language (Lithuanian) at work. And one respondent emphasized the use of foreign language for work-related issues. The results of the question (immigrants' use of languages for professional purposes, namely mother tongue, foreign language and/or host country's language, in a host country) show that the majority of the immigrants uses their mother tongues at work. The data were processed applying Excel software. Frequencies of the immigrants' answers were determined in order to reveal immigrants' use of languages for professional purposes, namely mother tongue, foreign language and/or host country's language, in a host country as shown in Table 1. 
SOCIETY. INTEGRATION. EDUCATION

Proceedings of the International Scientific Conference. Volume V, May $22^{\text {th }}-23^{\text {th }}, 2020.335-345$

Table 1 Frequencies of immigrants' answers onuse of languages for professional purposes

\begin{tabular}{|c|c|c|c|}
\hline Question & $\begin{array}{c}\text { Language for } \\
\text { professional purposes }\end{array}$ & $\begin{array}{c}\text { Number of } \\
\text { answers }\end{array}$ & Percentage \\
\hline Immigrants' use of languages & Mother tongue & 4 & $66.66 \%$ \\
\cline { 2 - 4 } \begin{tabular}{c} 
for professional purposes, \\
namely mother tongue, foreign \\
language and/or host country's \\
\cline { 2 - 4 } language, in a host country
\end{tabular} & $\begin{array}{c}\text { Foreign language } \\
\text { language }\end{array}$ & 1 & $16.66 \%$ \\
\hline
\end{tabular}

Source: the authors.

$n=6$

The frequencies of the immigrants' answers to the question (use of languages for professional purposes, namely mother tongue, foreign language and/or host country's language, in a host country) show that the majority of the respondents use their mother tongue at work (66.66\%), only $16.66 \%$ utilise a foreign language, and $16.66 \%$ of immigrants use the language of the host country at work.

The findings of the empirical study allow concluding that the respondents use their mother tongue, foreign language for professional purposes as well as host country's language at work in the host country, namely Lithuania. The summarizing content analysis (Mayring, 2004) of the data reveals that the immigrants mostly uses their mother tongues for doing the job in the host country.

\section{Conclusions}

Findings of theoretical analysis allow the establishment of inter-connections between immigrants' use of mother tongue, foreign language as well as host country's language for the implementation of their work in a host country.

Findings of the empirical study allow drawing a conclusion that the majority of immigrants uses their mother tongues at work in a host country. The empirical study if referred to Respondent 1 and 2 reveals that local companies employ immigrants for establishing business connections between the immigrant' host country as well as immigrants' origin country. Employment of immigrants who communicate in a language of the country local companies do business with is beneficial for all the stakeholders, namely host country' companies, partners of host country' companies, and the employed immigrant in terms of improvement of opportunities in the economic, social and civic life of their new country (Pieroni, d’Agostino, \& Lanari, 2019).

Implications for adult education in the field of teaching host country's language to immigrants to empower immigrants' employability imply the shift

- From language for integration purposes to language for professional purposes including entrepreneurship, 
Ahrens \& Zaščerinska, 2020. Immigrants' Use of Language for Professional Purposes in a Host Country: Implications for Adult Education

- From behaviourism as the teaching method to System-Constructivist approach to learning (Reich, 2005):

- $\quad$ human being's point of view depends on the subjective aspect,

- $\quad$ experience plays the central role in the knowledge construction process (Maslo, 2007).

The present study has some limitations. A limitation is participation of only immigrants from one city in one host country. Another limitation is that only few interviews were conducted. The research question has been newly formulated: What are employers' needs in use of immigrants' mother tongue, foreign language as well as host country's language at work in a host country? Future research will focus on the involvement of more respondents (immigrants) into the empirical study. Another direction of future work is the implementation of empirical studies with participation of other groups of respondents such as adult educators, employees, local government, wider community. A comparative study of different countries is of high research interest, too. Role of intermediary language of immigrants who are not able to perform in host country's language will be analysed. Motivation of language learning or use, as well as on social language functions will be investigated, too. The structured interview will be widened with sub-questions about particular situations and communication partners (friend, colleague, client, boss, etc) for a deeper analysis of immigrants' use of languages at work. Reasons of immigrations (employment, family, study, etc) will be investigated as well.

\section{References}

Adser`a, A., \& Pytlikov`a, M. (2016). Language and Migration. The Palgrave Handbook of Economics and Language, 342-372. London, UK.

Ahrens, A., Bassus, O., \& Zaščerinska, J. (2013). Bi-professional Curriculum in Higher Education: Context Analysis. Proceedings of 6th ICEBE International Conference on Engineeirng and Business Education Innovation, Entrepreneurship and Sustainability, Windhoek, Namibia, 7 - 10 October 2013, 101-107.

Ahrens, A., Purvinis, O., Zaščerinska, J., Micevičienė, D., \& Tautkus, A. (2018). Burstiness Management for Smart, Sustainable and Inclusive Growth: Emerging Research and Opportunities. IGI Global. DOI: 10.4018/978-1-5225-5442-4.

Cohen, L., Manion, L., \& Morrsion, K. (2003). Research Methods in Education. London and New York: Routledge/Falmer Taylor \& Francis Group.

Council of Europe Symposium. (2016). The linguistic integration of adult migrants: lessons from research. Strasbourg, 30 March - 1 April 2016. Council of Europe.

Eurostat. (2019). Asylum statistics. Retrieved from https://ec.europa.eu/eurostat/statisticsexplained/index.php/Asylum_statistics

Extramiana, C. (2012). Learning the language of the host country for professional purposes Outline of issues and educational approaches. Language Policy Unit, Council of Europe.

Kroplijs, A., \& Raščevska, M. (2004). Kvalitatīvās pētniecības metodes sociālajās zinātnēs. Rīga: RaKa. 
Lūka, I. (2007). Studentu profesionālās anglı valodas kompetences veidošanās tūrisma studijās. Promocijas darbs. Latvijas Universitāte, Rīga: Latvijas Universitāte.

Luka, I. (2008). Students and the educator's co-operation as a means of development of students' ESP competence. Paper presented at the European Conference on Educational Research, University of Goteborg, 10-12 September 2008. British Education Index data base: ID 172916. Retrieved from http://www.leeds.ac.uk/educol/documents/172916.htm

Mayring, P. (2004). Qualitative Content Analysis. In: U. Flick, E. Von Kardoff and I. Steinke (Eds.), A Companion to Qualitative Research (pp. 266-269). SAGE, UK, Glasgow.

Maslo, E. (2007). Transformative Learning Space for Life-Long Foreign Languages Learning. In: D. Cunningham, D. Markus, J. Valdmanis ... [u.c.] (Eds.), International Nordic-Baltic Region Conference of FIPLV Innovations in Language Teaching and Learning in the Multicultural Context 15-16 June, 2007, Riga, Latvia, pp. 38-46. Rīga: SIA "Izglītības solii".

Ose, L., Surikova, S., Fernāte, A., Daniela, L., Kalniṇa, D., \& Maslo, I. (2008). Jaunās paaudzes mācīšanās pamatskolā: mācīšanās panākumi kā kvalitatīvās pamatizglītības likumsakarības. ATEE Spring University Conference Teacher of the 21st Century: Quality Education for Quality Teaching, p. 442-449.

Pieroni, L., d'Agostino, G., \& Lanari, D. (2019). The effects of language skills on immigrant employment and wages in Italy. MPRA Paper No. 91725, posted 29 Jan 2019 16:22 UTC.

Pinto-Dobernig, I. (2008). Migration and Climate Change, Nr.31. International Organization for Migration.

Reich, K. (2005). Systemisch-konstruktivistische Pädagogik. Weinheim u.a. (Beltz).

Richards, J.C. (2001). Curriculum Development in Language Teaching. Cambridge: CUP.

Robbins, D. (2007). Vygotsky's and Leontiev's Non-classical Psychology Related to Second Language Acquisition, in International Nordic-Baltic Region Conference of FIPLV Innovations in Language Teaching and Learning in the Multicultural Context. Rīga: SIA "Izglìtības solii".

Saulescu, E., Saulescu, G., \& Capatan, S. (2009). State of Art of Plurilinguism in Romania. Implementation of the PLUSVALOR Project in Romania. Plurilinguism and First Language Valorisation Conference in Iasi, Romania 9th October 2009, Volume of conference proceedings, 19-22.

Taylor, P.C., \& Medina, M.N.D. (2013). Educational Research Paradigms: From Positivism to Multiparadigmatic. The Journal of Meaning-Centered Education, 1.

Zaščerinska, J. (2010). Professional Language in Language Education. Proceedings of 5th International scientific conference Theory for Practice in the Education of Contemporary Society of Riga Teacher Training and Educational Management Academy, 403-408.

Zaščerinska, J., \& Melnikova, J. (2014). Adults' Need For Foreign Language Competence as a Factor of Well-Being: A Comparative Study of Latvia and Lithuania's Cases. Adragogika, 1(5), 214-225.

Zaščerinska, J., Ahrens, A., \& Andreeva, N. (2013). A Theoretical Framework of Biprofessional Curriculum in Engineering Education. European Conference on Educational Research, Istanbul, Turkey. 9-13 September 2013. Retrieved from http://www.eeraecer.de/ecer-programmes/conference/8/contribution/22670/. ISBN 978-3-8442-5659-8 